DIGITAL COMMONS
@ UNIVERSITY OF SOUTH FLORIDA

Volume 2

Issue 2 Volume 2.2 (Fall 2012): Open Access

\section{ABO: Interactive Journal for Women in the Arts, 1640-1830}

2012

\title{
Supporting Women Scholars: How to get Things Done in Hard Times
}

Mona Narain

Texas Christain University, m.narain@tcu.edu

Follow this and additional works at: https://digitalcommons.usf.edu/abo

Part of the Dramatic Literature, Criticism and Theory Commons, Educational Methods Commons, Feminist, Gender, and Sexuality Studies Commons, and the Literature in English, British Isles Commons

\section{Recommended Citation}

Narain, Mona (2012) "Supporting Women Scholars: How to get Things Done in Hard Times," ABO: Interactive Journal for Women in the Arts, 1640-1830: Vol.2: Iss.2, Article 1.

http://dx.doi.org/10.5038/2157-7129.2.2.1

Available at: https://digitalcommons.usf.edu/abo/vol2/iss2/1

This Scholarship is brought to you for free and open access by Digital Commons @ University of South Florida. It has been accepted for inclusion in ABO: Interactive Journal for Women in the Arts, 1640-1830 by an authorized administrator of Digital Commons @ University of South Florida. For more information, please contact digitalcommons@usf.edu. 


\section{Supporting Women Scholars: How to get Things Done in Hard Times}

\section{Keywords}

faculty work, grants, hiring, recession, scholars, state of the profession, strategies, women

Creative Commons License

(c) (i) $\odot$

This work is licensed under a Creative Commons Attribution-No Derivative Works 3.0 License. 
During the Women's Caucus luncheon at the 2011 ASECS spring meeting in Vancouver, several caucus participants exchanged anecdotes about how the recession shaped their professional trajectory in significant ways and traded advice on ways to cope with challenges. The discussion at my table led to the roundtable for ASECS 2012 entitled "Funding, Grants, Hiring, Programs: Sharing Advice on How to get Things Done in Hard Times," chaired by myself and Kirsten Saxton (who, ironically, could not attend because of funding woes). Tellingly, similar discussions were taking place around the room; these discussions resulted in the panel, "Hard Times: Women Scholars and the Dynamics of Economic Recession," chaired by Linda Zionowski and Christine Clark-Evans. ${ }^{1}$ This synchronicity speaks, sadly, to the increasingly shared experience of negotiating "hard times" in an economically disastrous and politically charged climate in U.S. higher education. ${ }^{2}$

As more and more scholars face these challenges at all levels of their careers in academia under pressure from the economic downturn, legislative cuts, and increased political limitations placed on curricula and scholarly work, it has become clear that academics, perhaps especially women scholars, need to be more strategic and agile in the way they handle these current challenges.

Several studies conducted since 2008 have shown that faculty members and scholars face enormous pressure to perform more with less and less support. While this trend began well before 2008, the ongoing economic recession has accelerated the process of changing the working conditions for academics. Andrew Lounder et. al. in their recent article, "Following the Cuts: How Is the Recession Affecting Faculty Work?" have identified seven common measures that institutions of higher education have taken in response to the economic downturn and lack of funding: "(1) freezing hiring, (2) adjusting pay, (3) limiting professional development, (4) dismissing faculty and consolidating programs, (5) cutting academic unit budgets, (6) increasing teaching loads, and (7) shifting faculty appointments" $(20)^{3}$

In addition, federal and state funds supporting research have been reduced, forcing a sharper competition for such support. These panels brought together panelists from different types of institutions with a variety of administrative and leadership experiences to make short presentations at the ASECS 2012 meeting in San Antonio. Each presentation discussed strategies for professional success for scholars at various stages in their careers-junior and senior scholars-in obtaining funding for specialized projects not typically supported by large granting agencies; funding for endowed chair positions, program support and innovation; professional strategies for maintaining the integrity of academic work; the important work of mentoring and pedagogy; strategies for aiding the hiring of $18^{\text {th }}$-century tenure-track faculty at a time when such positions are being cut from department lines; the crisis that is the de-professionalization of faculty labor; and, perhaps most critically, strategies for forming productive coalitions within and across institutions to share information and to network for professional success and critical political change.

I thank the authors of these short essays, the participants in each panel, and the audiences at ASECS for their contributions to this discussion regarding the importance and scope of working across fields and locations (geographic and other) to effect change. In hard times, it is particularly important to form coalitions of support and share advice. $A B O$ 's welcome decision to 
publish these pieces provides a wider audience for these important ideas as well as the opportunity for further discussion, support, and action.

${ }^{1}$ We want to acknowledge the important contribution of Cynthia J. Keklar, who chose not to include her remarks for publication.

${ }^{2}$ We hope this publication engenders further discussion on the similarities and differences facing our colleagues across the globe.

${ }^{3}$ Lounder, Andrew, Chelsea Waugman, Mark Kenyon, Amy Levine Matthew Meekins, and Kerryann O'Meara, "Following the Cuts: How Is the Recession Affecting Faculty Work?" Liberal Education (Winter 2011): pp. 20-29. In a recent blog post Brian Farkas writes "the financial crisis is more difficult for these non profit educational institutions than businesses," because colleges are "held to higher moral standards" thus compromising how much and what they can do while still performing their intellectual and civic function. This adds a further burden on their employees to maintain high performance with little support and compensation ("Higher Education Will struggle through Recession," Huff Post Politics, 25 August, 2012). 